\title{
Morphological abnormalities in cladocerans related to eutrophication of a tropical reservoir
}

\author{
Rômulo R.R. de MELO ${ }^{1}$ Paula N. COELHO,${ }^{2 *}$ Maria J. dos SANTOS-WISNIEWSKI, ${ }^{1}$ Célio WISNIEWSKI, ${ }^{3}$ \\ Cristiana S. MAGALHÃES ${ }^{3}$
}

${ }^{1}$ Instituto de Ciências da Natureza, Universidade Federal de Alfenas (UNIFAL-MG), Gabriel Monteiro da Silva 700, 37130-001 Alfenas, Minas Gerais, Brazil; ${ }^{2}$ Departamento de Zoologia, Instituto de Biociências, Universidade Estadual Paulista (UNESP), CP. 510, 18618-000, Botucatu, São Paulo, Brazil; ${ }^{3}$ Instituto de Ciências Exatas, Universidade Federal de Alfenas (UNIFAL-MG), Gabriel Monteiro da Silva 700, 37130-001 Alfenas, Minas Gerais, Brazil

*Corresponding author: paulinhancoelho@gmail.com

\begin{abstract}
In zooplankton communities, morphological changes in Cladocera (Crustacea: Branchiopoda) may be resulting from water pollution by anthropogenic activities and/or natural events. The removal of vegetation cover, urbanization, agriculture and sewage release accelerate the eutrophication process in the aquatic environment. The present study seeks to demonstrate the occurrence of morphological abnormalities in cladocerans and relate the changes in the morphology and species composition to the physical and chemical parameters of the water. Samplings were made monthly in five stations on the Sapucai River compartment of Furnas Reservoir, located in the state of Minas Gerais, Brazil, from July 2013 to February 2014. The Furnas Reservoir has intense occupation of the surrounding areas by agriculture, urban and industrial activities and the installation of net cage fish cultures, which contribute to the water quality deterioration. Cladocerans samples were collected using a suction pump and plankton net (68 4 m mesh size) and concentrated from a volume of $400 \mathrm{~L}$. The measures of physical and chemical parameters of the water were obtained by a Horiba U-50 multi-sensor on the surface of water column and the density and morphology of Cladocera were made by microscopy. Twenty-three species of Cladocera were recorded with high organism densities of Chydoridae family species. Morphological abnormalities were observed in Daphnia gessneri, Ceriodaphnia silvestrii, Bosmina longirostris, Bosmina tubicen and Chydorus pubescens. The highest densities of C. pubescens with abnormalities were observed at sampling stations which had littoral characteristics and influences of sewage release. For C. pubescens, abnormalities were observed and classified into two types. The type 1 abnormality was considered an increase of length of intestine and size of its intestinal loop, whereas for type 2 was considered the occurrence of an intestine prolapse. The morphological abnormalities in cladocerans were described and compared to the ones described in the literature. From the results, it may observe that the abnormalities were probably resulting from continuous eutrophication process which has been occurring in the reservoir due to anthropogenic activities around the reservoir and a decrease in the water volume of the reservoir, caused by an unusual dry weather period in this region in the last years.
\end{abstract}

Key words: Morphological alterations; anthropic action; Chydoridae, zooplankton.

Received: November 2015. Accepted: September 2016.

\section{INTRODUCTION}

Changes in the structure and composition of aquatic communities and morphology of organisms may result from contamination of water by anthropogenic activities (Jakhar, 2013). The removal of vegetation cover, urbanization, agriculture and sewage release accelerate the eutrophication process in aquatic environments (Brito et al., 2011). Net cage fish cultures in reservoirs also contribute to increasing nutrient concentrations in water due to the waste of feed and fish's excreta (Santos et al., 2009; Mallasen et al., 2012).

The modifications in behavior and species composition of zooplankton community may occur with enrichment by nutrients and bloom of cyanobacteria, such as Microcystis aeruginosa, which produces toxic substances to aquatic biota (Lampert, 1982, 1987; Nanazato and Yasuno, 1985; Forsyth et al., 1990; Hanazato, 1991; Reichwaldt et al., 2013). Although many toxicity tests with cyanobacteria and zooplankton have already been carried out (Hanazato and Yasuno, 1987; Fulton and Paerl, 1988; Billoir et al., 2009; Cerbin et al., 2010; Shao et al., 2014), but the mechanism action of these substances on the zooplankton remains little known. In addition to the nutrient enrichment originated from the above causes, the continuous supply of pollutants such as hormones (Hense et al., 2004), drugs (Flaherty and Dodson, 2005) and pesticides (Hanazato, 2001) may decrease the organism reproduction rate, causing the removal of larger species, interfering in the energy transference of food chain (Sibley and Hanson, 2011) and in the biogeochemical cycles (Henry et al., 2004; Romo et al., 2013). 
Some authors have recorded Cladocera (Crustacea: Branchiopoda) morphological alterations generated by anthropogenic activities (Omair et al., 1999; ElmoorLoureiro, 2004; Sinev, 2000; Zanata et al., 2008; Sousa et al., 2011). Omair et al. (1999) reported abnormalities in cladocerans and copepods, in the Lake Michigan, and suggested that the abnormalities are a recent global phenomenon and probably due to the anthropogenic actions. Sinev (2000) reported abnormalities in sex-linked characters to males and ephippial females with a post-abdomen for Alona affinis, similar to that of the adult male, in a Russian lake. These changes may be due to a high metabolic rate and the rapid life cycle of cladocerans, which become them susceptible to chemical, physical or biological disturbances on environment (Tundisi and Matsumura-Tundisi, 2008).

The Chydoridae family (order Anomopoda) is the most diverse and usually occurs in the coastal region of water bodies associated with macrophytes, periphyton and sediment (Forró et al., 2008). Species of Chydoridae have short life cycle, active and dormant forms, asexual (parthenogenesis) and sexual reproduction (gamogenesis) (Dodson and Frey, 1991) as ecological attributes, among others, and some morphological attributes. The species richness for Chydorus genus is attributed to its successful body shape, which is globular or spherical, and with the bilateral compression and its adaptation capacity. These characters allow that species of this genus get into small gaps and became them abundant in a great variability of habitats (Fryer, 1968), besides they can have a wide geographic distribution (Dole-Olivier et al., 2000). The intense occupation of surrounding areas in the Furnas reservoir (Brazilian Southeast region) by agriculture, urban and industrial activities, and the installation of net cage fish cultures contribute to the water quality deterioration. Furthermore, there have been low rainfall levels in this region in recent years, leading to a decrease in the useful reservoir volume. In this context, this paper aims to relate the physical and chemical water parameters with the abnormalities in the morphology and species composition of cladocerans.

\section{METHODS}

\section{Study area}

The hydroelectric power plant of Furnas reservoir ( $20^{\circ} 42^{\prime} 49^{\prime \prime} \mathrm{S}, 46^{\circ} 06^{\prime} 40^{\prime \prime} \mathrm{W}$ ) is located in the Grande River Basin, southern of Minas Gerais State, Brazil (Fig. 1). It was formed by the damming of Grande and Sapucaí Rivers. It offers maximum length of $220 \mathrm{~km}$ and a perimeter of $3500 \mathrm{~km}$, occupies a flooded area of $1440 \mathrm{~km}^{2}$ and has a total water volume of 22.95 billion $\mathrm{m}^{3}$ (ANA, 2014).

Five stations on the Sapucaí River compartment of Furnas Reservoir were selected for studies. The stations were named $1 \mathrm{~A}, 1 \mathrm{~B}, 2,3 \mathrm{~A}$ and $3 \mathrm{~B}$. The stations $1 \mathrm{~A}$ $\left(21^{\circ} 23^{\prime} 50^{\prime \prime} \mathrm{S}, 4^{\circ} 04^{\prime} 05^{\prime \prime} \mathrm{W}\right)$ and $1 \mathrm{~B}\left(21^{\circ} 23^{\prime} 50^{\prime \prime} \mathrm{S}\right.$, $46^{\circ} 04^{\prime} 05^{\prime}$ 'W) are located at the entrance of the São Tomé River. They are influenced by agriculture activities and it is used for potable water supply for Alfenas Town. The station 2 is located at the entrance of the Pântano Stream $\left(21^{\circ} 23^{\prime} 52^{\prime \prime} \mathrm{S}, 45^{\circ} 59^{\prime} 06^{\prime \prime} \mathrm{W}\right)$. In this station, there is the contribution of residual water from wastewater treatment plant of Alfenas town. The stations 3A $\left(21^{\circ} 26^{\prime} 36^{\prime \prime} \mathrm{W}\right.$, $\left.46^{\circ} 04^{\prime} 38^{\prime \prime} \mathrm{W}\right)$ and $3 \mathrm{~B}\left(21^{\circ} 27^{\prime} 04^{\prime \prime} \mathrm{S}, 4^{\circ} 05^{\prime} 48^{\prime \prime} \mathrm{W}\right)$ are located below the station 2 and there is installation of net cage fish cultures for production of Nile tilapia.

\section{Sampling and data analysis}

The samples were monthly collected from July 2013 to February 2014, in the five stations. The water temperature, $\mathrm{pH}$, electrical conductivity and dissolved oxygen concentration were obtained by a Horiba U-50 multi-sensor on the surface of water column. Water transparency was estimated by Secchi disk. The total phosphorus and total dissolved phosphorus concentrations were determined by spectrophotometry analysis described in the Standard Methods for the Examination of Water and Wastewater (Rice et al., 2012). The chlorophyll $a$ concentrations were obtained by extraction with $90 \%$ cold acetone analysis (Golterman et al., 1978). The Carlson method (1977), modified by Toledo Junior et al., (1983), was used to calculate the trophic state index (TSI) considering the water transparency, chlorophyll $a$, total phosphorus and total phosphorus dissolved values.

Cladocerans were collected using a suction pump and plankton net ( $68 \mu \mathrm{m}$ mesh size) and concentrated from a volume of $400 \mathrm{~L}$. The samples were fixed with $4 \%$ formaldehyde solution. Qualitative samples were analyzed in full under stereoscopic microscope Zeiss Stemi 2000 with magnification up to $40 \mathrm{x}$ and the organism bodies were identified and photographed under light microscope Zeiss Scope A1, with image acquisition and magnification up to 400x. Quantitative samples were analyzed on subsamples. For cladocerans count, subsamples ranged from $5 \mathrm{~mL}$ to the entire sample were used and the organisms were counted in checkered acrylic sheets under stereoscopic microscope, with magnification up to 40x. The specialized literature was used for taxon identification. The cladoceran typical or atypical structure were detected based on a comparison with descriptions in specialized literature (Smirnov, 1996; Elmoor-Loureiro, 1997).

Canonical Correspondence Analysis (CCA) were performed by CANOCO 4.5 software (ter Braak and Šmilauer 2002). It was used to verify the influence of limnological variables on cladocerans densities (with and without morphological abnormalities) and correlated them with the stations and sampling dates. 


\section{RESULTS}

During the study period, noticeable changes in the physical and chemical properties of the water in Furnas Reservoir were observed, reflecting well-defined the wet (December 2013 to February 2014) and dry (July-November, 2013) seasonal climatic periods.

The average $\mathrm{pH}$ was near neutrality. The water temperature ranged from $19.4^{\circ} \mathrm{C}$ to $31.4^{\circ} \mathrm{C}$ and the highest temperatures were registered during the wet period. Electric conductivity ( 36 to $84 \mu \mathrm{S} \mathrm{cm}^{-1}$ ) was considered low when compared to other reservoirs, being the highest value recorded at station $3 \mathrm{~B}$, that is a littoral region and it is influenced by Pântano Stream, which receive residual water from wastewater treatment plant of Alfenas town and by presence of net cage fish culture. In this station also occurred the highest total phosphorous concentration, $35.2 \mu \mathrm{g} \mathrm{L}^{-1}$. Oxygen concentrations (average of $8.5 \mathrm{mg}$ $\mathrm{L}^{-1}$ ) were high evidencing that the reservoir is a well oxygenated. The suspension matter values ranged from 4.5 up to $11.5 \mathrm{mg} \mathrm{L}^{-1}$, being the highest values recorded during the wet season due to the carrying by rainwater.

There was an increase of the trophic level of the aquatic environment due to the reduction of water reservoir volume and the continuous release of organic and inorganic materials from natural and anthropogenic activities. The stations $1 \mathrm{~A} 1 \mathrm{~B}, 3 \mathrm{~A}$ and $3 \mathrm{~B}$ were classified as eutrophic during the dry season and oligotrophic in the wet season, whereas the station 2 was classified as eutrophic throughout the study period. Also, there was the occurrence of bloom of cyanobacteria Microcystis aeruginosa during the dry sea-

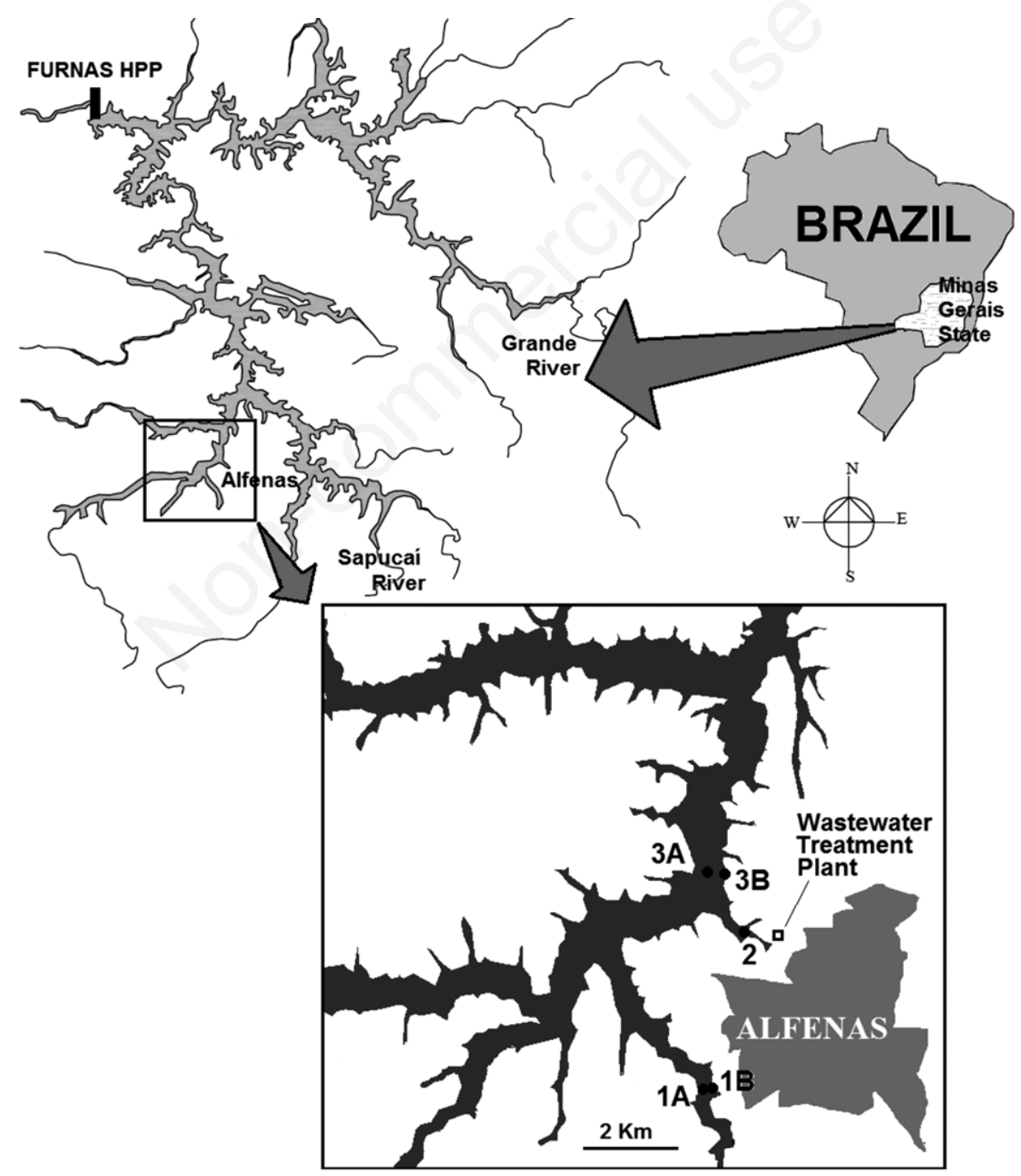

Fig. 1. Furnas Reservoir $\left(20^{\circ} 42^{\prime} 49^{\prime}\right.$ S, $\left.46^{\circ} 06^{\prime} 40^{\prime \prime} \mathrm{W}\right)$ region. The five sampling stations (1A, 1B, 2, 3A and 3B) are shown, in Sapucaí River compartiment. 
son, for every sampling station. It was probably caused by the enrichment of the aquatic ecosystem, indicated by the highest concentrations of chlorophyll $a$ in the dry season (from 24.9 to $35.2 \mu \mathrm{g} \mathrm{L}^{-1}$ ) when compared to the wet season (1.0 to $\left.10.4 \mu \mathrm{g} \mathrm{L}^{-1}\right)$ and the high densities of cyanobacteria observed in the analysis of zooplankton.

Twenty-three taxa of Cladocera were recorded: Macrothricidae (1), Moinidae (1), Sididae (3), Daphnidae (5), Chydoridae (8) and Bosminidae (4) family. High individuals density of Chydoridae occurred from July to November 2013, mainly in stations 2, 3A and 3B. It probably occurred due to the reduction in the reservoir water volume, becoming these stations shallow and with high presence of macrophytes. This family is typical of littoral region and lives associated to macrophytes and sediment. Chydorus pubescens Sars, 1991 was dominant among Chydoridae and occurred in high densities in stations $3 \mathrm{~A}$ and 3B, in December 2013. Also, it was observed the occurrence of ephipial females and males of Alona sp.

Morphological abnormalities were observed in some species of cladocerans. Daphnia gessneri Herbst, 1967 shows a deformation of the rostrum and a folded tail spine in only one individual, at the station 3A, in August 2013 (Fig. 2). Also, abnormalities were observed in the intestine of Ceriodaphnia silvestrii Daday, 1902, and Bosmina longirostris (O. F. Müller, 1785) in a single individual of each species. Abnormalities for Bosmina tubicen Brehm, 1953 were found at $6.3 \%$ from the population at the station $3 \mathrm{~B}$. However, for $C$. pubescens the abnormalities occurred at high population rate and were classified in type 1 and type 2 abnormalities. Type 1 had increased length of intestine and size of its intestinal loop, whereas the type 2 had an intestine prolapse (Fig. 3).

The abnormalities were observed for every station studied in the dry season for C. pubescens, mainly at $3 \mathrm{~A}$ and 3B stations, in October and December 2013, where were observed high abnormality densities for type 1 (from 5.64 up to 22.33 ind $\mathrm{m}^{-3}$ ) and high type 2 abnormality density $\left(8.89\right.$ ind $\left.\mathrm{m}^{-3}\right)$ at station 2 in October (Fig. 4). The total abnormalities (type $1+$ type 2 ) occurred at $~ 75 \%$ and $42 \%$ of the total of individuals of this species in dry and wet seasons respectively, in average. The highest rates, associated to high densities of individuals, were registered at 1B (97\%), 3A (98\%) and 3B (93\%) stations, in October.
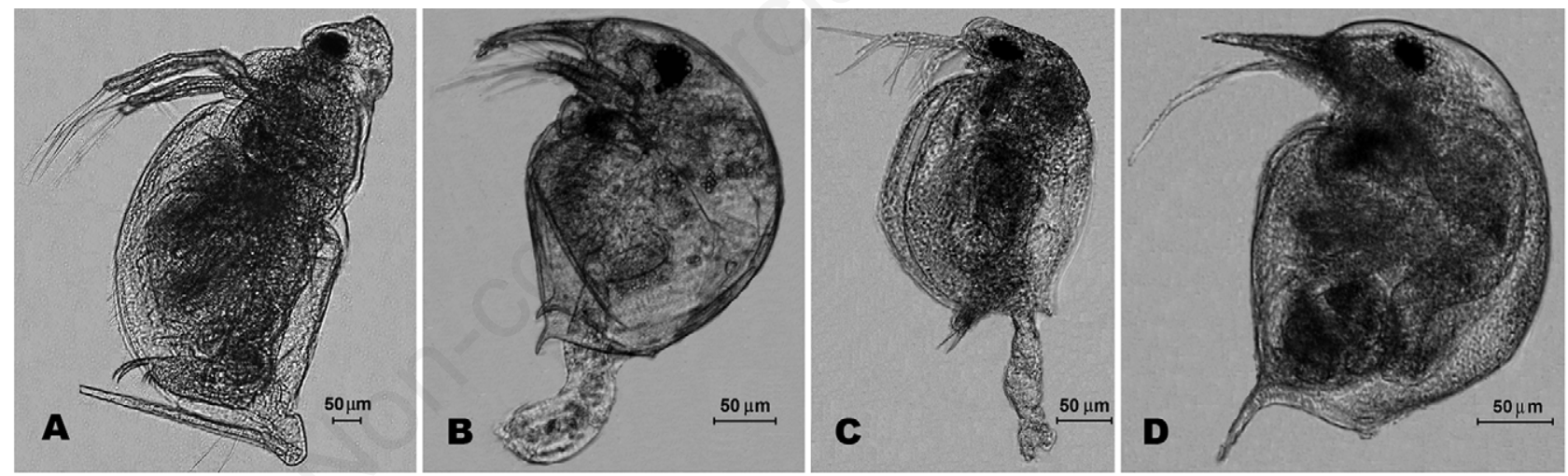

Fig. 2. Abnormalities in A, Daphnia gessneri; B, Bosmina longirostris; C, Ceriodaphnia silvestrii, and D, Bosmina tubicen species.
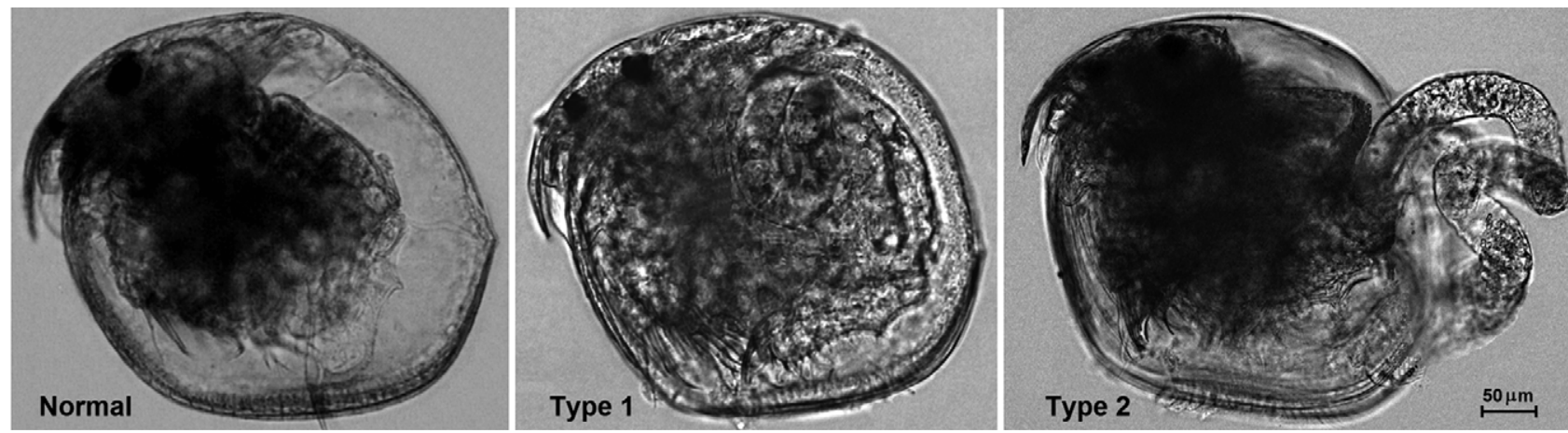

Fig. 3. Ch. pubescens female: normal (without abnormalities), type 1 and type 2 abnormalities. 
These sampling stations are in the littoral zone or with low depth and they have been influenced by sewage release. During the wet season, mainly in January and February $2014, C$. pubescens had a low density and/or no abnormalities, probably due to dilution caused by rainwater and subsequent decreasing of the trophic level.

The Canonical Correspondence Analysis (CCA) indicated that presence of normal individuals of $C$. pubescens only was correlated with lower depth, presence of suspended matter, lower $\mathrm{pH}$ and higher temperature of the station samplings (Fig. 5). Presence of C. pubescens organisms with type 1 abnormality was more correlated with lower total phosphorus and higher inorganic phosphate concentrations, while type 2 abnormality was more correlated with higher chlorophyll $a$ concentration. The most part of sampling months of stations $3 \mathrm{~A}$ and $3 \mathrm{~B}$ were correlated with higher total phosphorus, inorganic phosphate and chlorophyll $a$ concentrations, probably due to the release of residual water from wastewater treatment plant of Alfenas Town.
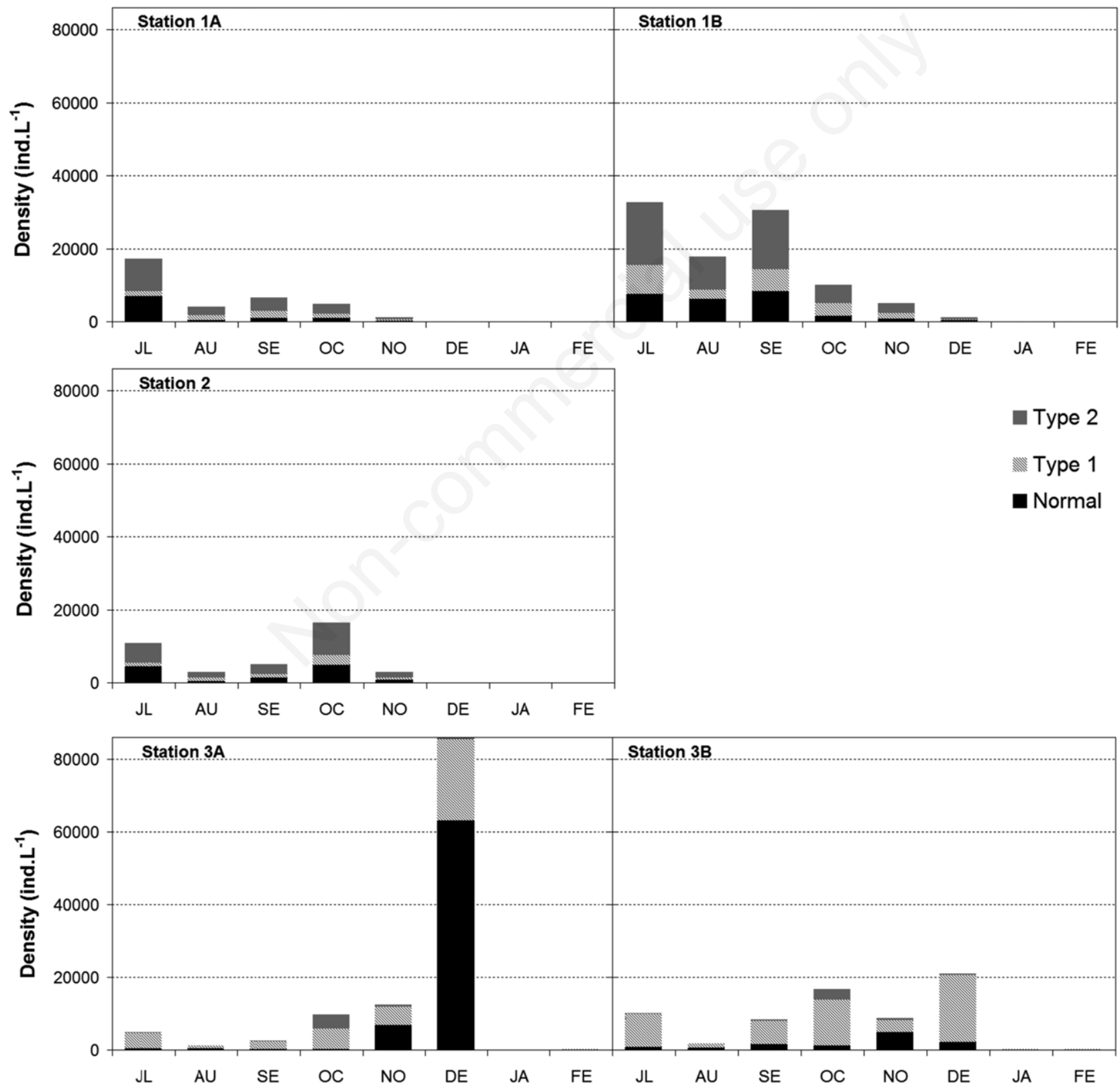

Fig. 4. Organism density with type 1 and type 2 abnormalities and Normal (no abnormalities). 


\section{DISCUSSION}

The dry season (2013 and 2014) was an unusual period due to lack of rain when compared to previous dry seasons, in Brazil Southeastern region. Furthermore, the electric power production caused a decreasing of the useful reservoir volume from $57.4 \%$ in 2013 to $24.9 \%$ in 2014, from its maximum capacity (ONS, 2014). This reduction associated with continued releasing of particulate matter, which caused the increasing of nutrients concetration concentration in the aquatic environment and intensified the eutrophication in the study area. Pinto-Coelho et al. (2005) noted that this reservoir is changing from oligotrophic to mesotrophic, and even it has been classified as eutrophic in some its portions. Santos et al. (2010) mentioned that the Sapucaí River compartment of Furnas Reservoir is still oligotrophic, but observed occasional the trophic level decrease and occurrence of cyanobacteria blooms, suggesting the nutrient enrichment. The increase of trophic level index was also observed in this study. The station 2 was classified as eutrophic throughout the study period due to the release of residual water from wastewater treatment plant from Alfenas Town.

Species richness of cladocerans (23 species) was higher than that observed by Brito et al. (2011), which recorded 15 species. At eutrophic stations, there was the dominance of smaller species such as Chydoridae representatives that are less sensitive to cyanobacteria toxicity, low dissolved oxygen and food concentrations, found in these environments (Chislock et al., 2013). The highest species richness of the Chydoridae ( 8 species) was expected, since the stations were shallow and there was occurrence of macrophytes, which support the development of typical species of the littoral zone (Sousa and ElmoorLoureiro, 2008). Several male individuals of Alona sp. were found between July to October 2013, at stations 1A, $1 \mathrm{~B}, 2$ and $3 \mathrm{~B}$. It could mean that the environment conditions were unfavorable, because male individuals are generated to perform sexual reproduction and thus increase the species survival chances.

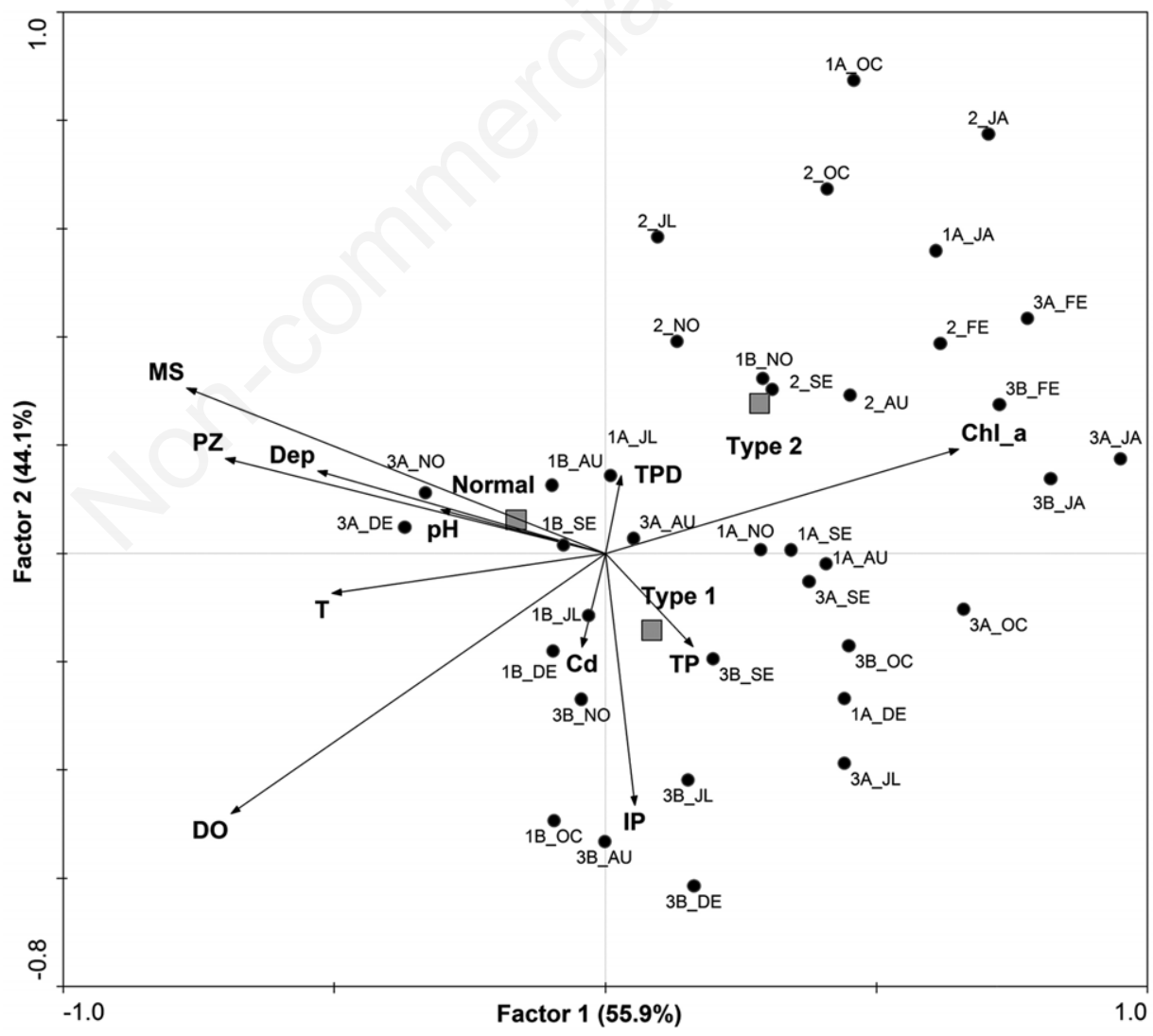

Fig. 5. CCA ordination diagram to C. pubescens organisms' density without abnormalities (Normal) and with Type 1 and Type 2 abnormalities. T, temperature; Cd, electrical conductivity; Dep, depth; PZ, photic zone; TP, total phosphorus; IP, inorganic phosphate; TPD, total dissolved phosphorus; Chl, chlorophyll $a$; MS, suspension matter (organic and inorganic); DO, dissolved oxygen concentrations, from Furnas Reservoir samplings (1A, 1B, 2, 3A and 3B). The last two letters attached to station names correspond to the sampling month. 
According to Smirnov (1974), abnormalities of various parts of body are sometimes common in the Chydoridae and usually are detected at small minority of the population. They could be from embryonic origin or results of some physical injury during postembryonic development. In the Furnas Reservoir, the morphological abnormalities were observed in several species of Cladocera and in high rate for $C$. pubescens. It may have been resulting of anthropogenic influence that occur in the surroundings of the Furnas Reservoir and have caused deterioration in water quality and constant blooms of Microcystis aeruginosa. Several studies showed that Cyanobacteria are harmful to herbivores zooplankton (Lampert, 1982; Hanazato and Yasuno, 1987; Gliwicz and Lampert, 1990). They have low nutritional value, cause blockage of the digestive tract, blocking food intake, and produce toxins. A study carried out in a hypereutrophic pond in Rio de Janeiro found that blooms of Microcystis aeruginosa are potentially damaging for populations of cladocerans (Ferrão-Filho, 2009). Hanazato and Yasuno (1987) observed that the rate of growth and reproduction of Moina micrura Kurz, 1874 were affected by Microcystis sp when cultured in the laboratory. Likewise, Reinikainen et al. (1994) found in their studies that low Microcystis sp. concentrations were responsible for the death causes of Daphnia pulex Leydig, 1860. Christoffersen (1996) reported that cyanotoxins has effects on growth, survival, feeding, behavior in the development and establishment of susceptible species, bioaccumulation of toxins in the food chain, and also species diversity decreasing. The C. pubescens abnormalities cannot be associated directly to Cyanobacteria bloom because this species probably does not feed on Microcystis. Besides $C$. pubescens is morphologically similar to Chydorus sphaericus and, according to Fryer (1968), this species feed fine organic and inorganic particles and rarely diatoms and other no identified large particles.

The zooplankton community can be affected by release of pollutants. The effect of toxic substances in sewage on cladocerans were reported by several studies (Abdellatif, 1993; Monda et al., 1995; Arauzo and Valladolid, 2003; Sotero-Santos et al., 2006; Xiang et al., 2012). In Furnas Reservoir were detected high pesticide concentrations in the water near the coffee cultures farms, which can cause changes in the zooplankton community (Santos-Neto and Siqueira, 2005). Stampfli et al. (2011) evaluated the impact of pesticides on zooplankton community in experiments with mesocosms and noted that the largest organisms were eliminated, causing changes in the trophic chain. The reproductive cycles for other aquatic species were also affected.

In this study, abnormalities were observed in the intestine morphology of various specimens of $C$. pubescens. For this, they were classified to type 1 and type 2 abnor- malities. Smirnov (1974) and Røen (1968) also reported malformation of the post-abdominal claws and on the arrangement of the anal spinules. Dias (1999) observed prolapse (type 2) and intestinal partial disruption of chitin among segments in Acartia lilljeborgi (Crustacea Copepoda). Montú and Gloeden (1982) also observed these abnormalities in other species of Copepoda. Toxicity tests with cyanotoxin Microcystin - LR, which are present in Microcystis aeruginosa, show that at high concentrations of this cyanotoxin there was bioaccumulation and caused structural changes in the epithelial cells of the alimentary duct. There was a loss of structures which perform the link between cells and the cells with epidermis (Chen et al., 2005; Rohrlack et al., 2005). In this study, the abnormalities were observed in Chydorus pubescens and occurred in every station in the dry season for every sampling in high rates ( $75 \%$ in average) of population. On the other hand, there were low rates ( $42 \%$ in average) in wet season. The difference can be explained by useful water volume of Furnas Reservoir (lowest in dry season), which change of nutrients concentration, and the weather conditions.

According to CCA results, the occurrence of $C$. pubescens was more correlated to depth and the photic zone of water column. This species is typical of regions with coastal characteristics and presence of macrophytes, since it has scraper habit (Santos-Wisniewski et al., 2006). The presence of the type 1 abnormality was more correlated to total phosphorus and dissolved phosphorus concentrations, at stations $3 \mathrm{~A}$ and $3 \mathrm{~B}$, which can be associated with presence of organic matter from releasing of residual water (and nutrients) of the wastewater treatment plant and feeding and fish excreta from net cage fish cultures (Santos et al., 2009). The type 2 abnormality was more associated with chlorophyll $a$ concentration at stations 2, 3A and 3B, probably due to the bloom of cyanobacteria which occurred at these stations. However, the cited variables contributed to the CCA factors for both abnormality types.

Abnormalities in other species of cladocera were also observed for Ceriodaphnia silvestrii, Daphnia gessneri, Bosmina longirostris and Bosmina tubicen, in this study. Kotov et al. (2009) also observed morphological variability in Bosmina tanakai, a species which occur in Japan. Other authors observed abnormalities in cladocerans which may be associated with environmental factors, in Brazilian water bodies, as this study. Chemical contaminants or bacteria and viruses, may have caused changes in helm, rostrum and the ventral margin of the carapace of some species of daphnids, in reservoir cascade of medium and low Tietê River (Zanata et al., 2008). Iron bioaccumulation by Coronatella monacantha Sars, 1901 may have caused abnormalities in the labrum of the keel in species of a stream in Ceará State, Brazilian Northeast (Sousa et al., 2011). Organic pollution in Apipucos Reservoir may have caused the high percentage of abnormali- 
ties in Ilyocryptus spinifer Herrick, 1882 post-abdomen (Elmoor-Loureiro, 2004).

\section{CONCLUSIONS}

The results of this study indicate a strong correlation between high concentrations of nutrients and bloom of cyanobacteria with the occurrence of abnormalities in some species the Cladocera, especially for C. pubescens species, probably intensified by an unusual period of dry weather in the study period, in Furnas Reservoir.

\section{ACKNOWLEDGMENTS}

We thank to Eletrobrás Furnas S.A. (Programa de P\&D Aneel) and FAPEMIG (Biota Minas APQ-0354909), by financial support.

\section{REFERENCES}

Abdellatif EM, Ali OM, Khalil IF, Nyonje, BM, 1993. Effects of sewage disposal into the White Nile on the plankton community. Hydrobiologia 259:195-201.

ANA (Agência Nacional de Águas), 2014. [Boletim de Monitoramento do Reservatório de Furnas/Superintendência de Usos Múltiplos e Eventos Críticos].[Report in Portuguese]. Agência Nacional de Águas, Brasilia 2:1-13.

Arauzo M, Valladolid M, 2003. Short-term harmful effects of unionized ammonia on natural populations of Moina micrura and Brachionus rubens in a deep waste treatment pond. Water Res. 37:2547-2554.

Billoir E, Ferrão-Filho AS, Delignette-Muller ML, Charles S, 2009. DEBtox theory and matrix population models as helpful tools in understanding the interaction between toxic cyanobacteria and zooplankton. J. Theor. Biol. 258: 380-388.

Brito SL, Maia-Barbosa PM, Pinto-Coelho RM, 2011. Zooplankton as an indicator of trophic conditions in two large reservoirs in Brazil. Lakes Reserv. Res. Manage. 16:253-264.

Cerbin S, Kraak MHS, de Voogt P, Visser PM, Van Donk E, 2010. Combined and single effects of pesticide carbaryl and toxic Microcystis aeruginosa on the life history of Daphnia pulicaria. Hydrobiologia 643:129-138.

Chen W, Song L, Ou D, Gan N, 2005. Chronic toxicity and responses of several important enzymes in Daphnia magna on exposure to sublethal microcystin-LR. Environ. Toxicol. 20:323-330.

Chislock MF, Doster E, Zitomer RA, Wilson AE, 2013. Eutrophication: causes, consequences, and controls in aquatic ecosystems. Nat. Educ. Knowl. 4:10.

Christoffersen K, 1996. Ecological implications of cyanobacterial toxins in aquatic food webs. Phycologia 35:42-50.

Dias CD, 1999. Morphological abnormalities os Acartia lilljeborgi (Copepoda, Crustacea) in the Espírito Santo Bay (ES, Brazil). Hydrobiologia 394: 249-251.

Dodson SI, Frey DG, 1991. Cladocera and other Branchiopoda, p. 723-783. In: J.H. Thorp and A.P. Covich (eds.), Ecology and classification of North American freshwater invertebrates. Elsevier Academic Press.

Dole-Olivier MJ, Galassi DMP, Marmonier P, Châtelliers MC, 2000. The biology and ecology of lotic microcrustaceans. Freshwater Biol. 44:63-91.

Elmoor-Loureiro LMA, 1997. [Manual de identificação de Cladóceros límnicos do Brasil].[Book in Portuguese]. Universa, Brasilia: $156 \mathrm{pp}$.

Elmoor-Loureiro LMA, 2004. Morphological abnormalities in the cladoceran lyocryptus spinifer (Apipucos reservoir, Pernambuco State, Brazil). Braz. J. Biol. 64:53-58.

Ferrão-Filho AS, Soares MC, Rocha MLA, Magalhães VF, Azevedo, SMFO, 2009. [Florações de cianobactérias tóxicas no reservatório do Funil: dinâmica sazonal e consequências para o zooplancton].[Article in Portuguese]. Oecol. Bras. 13: 329-345.

Flaherty CM, Dodson SI, 2005. Effects of pharmaceuticals on Daphnia survival, growth, and reproduction. Chemosphere 61:200-207.

Forró L, Korovchinsky NM, Kotov AA, Petrusek A, 2008. Global diversity of cladocerans (Cladocera; Crustacea) in freshwater. Hydrobiologia 595:177-184.

Forsyth JW, Hanlon RJ, Lee PG, 1990. A formulary for treating cephalopod mollusk diseases, p. 51-63. In: F.O. Perkins and T.C. Cheng (eds.), Pathology in marine science. Academic Press, Inc.

Fryer G, 1968. Evolution and adaptive radiation in the Chydoridae (Crustacea: Cladocera): a study in comparative functional morphology and ecology. Philos. T. R. Soc. B 254:221-385.

Fulton III RS, Paerl HW, 1988. Effects of the blue-green alga Microcystis aeruginosa on zooplankton competitive relations. Oecologia 76:383-389.

Gliwicz MZ, Lampert W, 1990. Food thresholds in Daphnia species in the absence and presence of blue-green filaments. Ecology 71:691-702.

Golterman HL, Clymo RS, Ohnstad MAM, 1978. Methods for physical and chemical analysis of freshwaters. 2. Blackwell Scientific, Oxford: 213 pp.

Hanazato T, 1991. Pesticides as chemical agents inducing helmet formation in Daphnia ambigua. Freshwater Biol. 26:419-424.

Hanazato T, 2001. Pesticide effects on freshwater zooplankton: an ecological perspective. Environ. Pollut. 112:1-10.

Hanazato T, Yasuno M, 1987. Effects of a carbamate insecticide, carbaryl, on the summer phyto and zooplankton communities in ponds. Environ. Pollut. 48:145-159.

Henry R, Carmo CF, Bicudo DC, 2004. Trophic status of a Brazilian urban reservoir and prognosis about the recovery of water quality. Acta Limnol. Bras. 16:251-262.

Hense BA, Severin GF, Welzl G, Schramm KW, 2004. Effects of $17 \alpha$-ethinylestradiol on zoo-and phytoplankton in lentic microcosms. Anal. Bioanal. Chem. 378:716-724.

Jakhar P, 2013. Role of phytoplankton and zooplankton as health indicators of aquatic ecosystem: a review. Int. J. Innov. Res. Stud. 2:489-500.

Kotov AA, Ishida S, Taylor DJ, 2009. Revision of the genus Bosmina Baird, 1845 (Cladocera: Bosminidae), based on evidence from male morphological characters and molecular phylogenies. Zool. J. Linn. Soc. 156:1-51.

Lampert W, 1982. Further studies on the inhibitory effect of the 
toxic blue-green Microcystis aeruginosa on the filtering rate of zooplankton. Arch. Hydrobiol. 95:207-220.

Lampert W, 1987. Laboratory studies on zooplankton/cyanobacteria interactions. New Zeal. J. Mar. Fresh. 21:483-490.

Mallasen M, Barros HP, Traficante DP, Camargo ALS, 2012. Influence of a net cage tilapia culture on the water quality of the Nova Avanhandava reservoir, São Paulo State, Brazil. Acta Sci. Biol. Sci. 34:289-296.

Monda DP, Galat DL, Finger SE, 1995. Evaluating ammonia toxicity in sewage effluent to stream macroinvertebrates: I. A multilevel approach. Arch. Environ. Contam. Toxicol. 28:378-384.

Montú M, Gloeden I, 1982. Morphological alterations in Acartia tonsa (Saco da mangueira, lagoa dos Patos, Brazil). Arq. Biol. Tecnol. 25:361-369.

Nanazato T, Yasuno M, 1985. Population dynamics and production of cladoceran zooplankton in the highly eutrophic Lake Kasumigaura. Hydrobiologia 124:13-22.

Omair M, Vanderploeg HA, Jude DJ, Fahnenstiel GL, 1999. First observations of tumor-like abnormalities (exophytic lesions) on Lake Michigan zooplankton. Can. J. Fish. Aquat. Sci. 56:1711-1715.

ONS (Operador Nacional do Sistema Elétrico do Brasil), 2014. [Volume útil dos principais reservatórios].[Report in Portuguese]. Available from: http://www.ons.org.br/ historico /percentual_volume_util.aspx

Pinto-Coelho RM, Pinel-Alloul B, Méthot G, Havens KE, 2005. Crustacean zooplankton in lakes and reservoirs of temperate and tropical regions: variation with trophic status. Can. J. Fish. Aquat. Sci. 62:348-361.

Reichwaldt ES, Song H, Ghadouani A, 2013. Effects of the distribution of a toxic Microcystis bloom on the small scale patchiness of zooplankton. PloS One 8:e66674.

Reinikainen M, Ketola M, Walls M, 1994. Effects of the concentration of toxic Microcystis aeruginosa and an alternative food on the survival of Daphnia pulex. Limnol. Oceanogr. 39:424-432.

Rice EW, Baird RB, Eaton AD, Clesceri LS, 2012. Standard methods for the examination of water and wastewater. 22. American Public Health Association, Washington: 724 pp.

Røen VI, 1968. Notes on abnormalites in freshwater Entomostraca with a description of a new subspecies, Alona affinis deudata. Vidensk. Maddr. Densk. Natuel. Foren. 131 153-159.

Rohrlack T, Christoffersen K, Dittmann E, Nogueira I, Vasconcelos V, Börner T, 2005. Ingestion of microcystins by Daphnia: Intestinal uptake and toxic effects. Limnol. Oceanogr. 50:440-448.

Romo S, Soria J, Fernandez F, Ouahid Y, Barón-Solá A, 2013. Water residence time and the dynamics of toxic cyanobacteria. Freshwater Biol. 58:513-522.

Santos RM, Rocha GS, Rocha O, Santos-Wisniewski MJ, 2009. Influence of net cage fish cultures on the diversity of the zooplankton community in the Furnas hydroelectric reservoir, Areado, MG. Aquacult. Res. 40:753-776.

Santos RM, Negreiros NF, Silva LC, Rocha O, Santos-Wisniewski MJ, 2010. Biomass and production of Cladocera in Furnas Reservoir, Minas Gerais, Brazil. Braz. J. Biol. 70: 879-887.

Santos-Neto AJ, Siqueira MEPB, 2005. [Análise de praguicidas organofosforados em água por extração em fase sólida (SPE) utilizando discos $\mathrm{C} 18$ e cromatografia em fase gasosa: avaliação da contaminação do reservatório de Furnas (MGBrasil)].[Article in Portuguese]. Quim. Nova. 28: 747-750.

Santos-Wisniewski MJ, Rocha O, Matsumura-Tundisi T, 2006. Aspects of the life cycle of Chydorus pubescens Sars, 1901 (Cladocera, Chydoridae). Acta Limnol. Bras. 18:305-310.

Shao YQ, Deng DG, Meng MR, Zhang XL, Li F, 2014. Effects of colonial Microcystis aeruginosa and interspecific competition on the population dynamics and resting egg formation of two cladocerans. J. Freshwater Ecol. 29:213-223.

Sibley PK, Hanson ML, 2011. Ecological Impacts of Organic Chemicals on Freshwater Ecosystems, p. 138-164. In: F Sánchez-Bayo, PJ van den Brink, RM Mann (eds.), Ecological Impacts of Toxic Chemicals. Bentham Science Publishers.

Sinev AY, 2000. Postembryonal development of male and abnormal sexual individuals of Alona affinis (Leydig, 1860) (Anomopoda, Chydoridae). Hydrobiologia 437:197-202.

Smirnov NN, 1974. [Chydoridae of the world's fauna].[Book in Russian]. Nauka, Leningrad: 644 pp.

Smirnov NN, 1996. Cladocera: the Chydorinae and Sayciinae (Chydoridae) of the World. Guides to the identification of the macroinvertebrates of the continental waters of the world. 11. SPB Academic Publishing: 197 pp.

Sotero-Santos RB, Silva CRSE, Verani NF, Nonaka KO, Rocha O, 2006. Toxicity of a cyanobacteria bloom in Barra Bonita Reservoir (Middle Tietê River, São Paulo, Brazil). Ecotox. Environ. Safe. 64:163-170.

Sousa FDR, Elmoor-Loureiro LMA, 2008. [Cladóceros fitófilos (Crustacea, Branchiopoda) do Parque Nacional das Emas, estado de Goiás].[Article in Portuguese]. Biota Neotrop. 8:159-166.

Sousa FDR, Elmoor-Loureiro LMA, Souza MBG, 2011. Occurrence of abnormalities on labral keel of Coronatella monacantha (Cladocera, Anomopoda, Chydoridae) in a population from Ceará, Brazil. Braz. J. Biol. 71:797-798.

Stampfli NC, Knillmann S, Liess M, Beketov MA, 2011. Environmental context determines community sensitivity of freshwater zooplankton to a pesticide. Aquat. Toxicol. 104:116-124.

ter Braak CJF, Šmilauer P, 2002. CANOCO ver. 4.5. BiometrisPlant Research International, Wageningen, The Netherlands.

Toledo Junior AP, Talartico M, Chinez SJ, Agudo EG, 1983. [A aplicação de modelos simplificados para a avaliação do processo de eutrofização em lagos e reservatórios tropicais, p. 1-34].[Article in Portuguese]. Proceedings XII Congresso Brasileiro de Engenharia Sanitária e Ambiental, Camboriú.

Tundisi JG, Matsumura-Tundisi T, 2008. [Limnologia].[Book in Portuguese]. Oficina de Textos, São Paulo: 632 pp.

Xiang F, Geng L, Lü K, Zhang J, Minter EJ, Yang Z, 2012. Effect of long-term nitrite exposure on the cladoceran Daphnia obtusa: survival, moults, and reproduction. Biochem. Syst. Ecol. 41:98-103.

Zanata LH, Espíndola ELG, Rocha O, Pereira RHG, 2008. Morphological abnormalities in Cladocera (Branchiopoda) in a cascade of reservoirs in the middle and lower Tiete river (Sao Paulo, Brazil). Braz. J. Biol. 68:681-682. 